\title{
The association of Val109Asp polymorphic marker of intelectin 1 gene with abdominal obesity in Kyrgyz population
}

\author{
Jainagul Isakova1 ${ }^{1 *}$ Elnura Talaibekova', Denis Vinnikov ${ }^{1,2}$, Nazira Aldasheva ${ }^{1,3}$, Erkin Mirrakhimov $^{3}$ \\ and Almaz Aldashev ${ }^{1}$
}

\begin{abstract}
Background: The aim of this study was to quantify the association of Val109Asp polymorphism of intelectin 1 (ITLN1) gene with the abdominal obesity (AO) in Kyrgyz population.

Methods: Patients admitted to annual screening at a local outpatient facility were enrolled or this study. We genotyped 297 nonrelated adults of Kyrgyz ethnicity, of whom 127 were AO patients, including 46 men and 81 women with the mean age $53.2 \pm 7.1$ years, and 170 non-obese controls, including 61 men and 109 women with the mean age $52.0 \pm 9.0$ years. AO was defined as having waist circumferences $\geq 102 \mathrm{~cm}$ in men and $\geq 88 \mathrm{~cm}$ in women. We used PCR-RFLP method to define Val109Asp polymorphism of ITLN1 gene.

Results: Asp109Asp, Asp109Val and Val109Val genotypes were found in 48\%, 40\%, and 12\% of AO patients respectively, and in 53\%,43\%, and $4 \%$ of controls, whereas Val109Val homozygous genotype of ITLN1 gene Val109Asp polymorphic marker was significantly more prevalent in AO patients. In Kyrgyz population, Val109Val genotype of ITLN1 gene increased the risk of $A O$ (odds ratio (OR) 3.12, 95\% Cl 1.23-7.90). Asp109Asp homozygous genotype, on opposite, was not associated with this condition (OR 0.82 , 95\% Cl 0.53-1.30). Finally, the allelic variants of Val109Asp polymorphism of ITLN1 gene were not associated with AO.

Conclusion: Significant increase in the frequency of Val109Val genotype of ITLN1 gene in AO patients may be indicative of some potential role of ITLN1 gene in molding genetic predisposition to AO in the Kyrgyz. This requires further elaboration in the future studies.
\end{abstract}

Keywords: Intelectin 1 gene, Val109Asp polymorphism, Abdominal obesity, Kyrgyz population

\section{Background}

There is a trend towards growing prevalence of overweight and obese people in almost all populations in the twenty-first century [1]. Compared to 80-90s of the last century, the number of overweight people and those with obesity, including abdominal obesity rose almost two-fold, reaching the levels of $30.8 \%, 25.7 \%$ and $52.3 \%$ in Kyrgyz Republic [2]. In the last decades, eating patterns and the lifestyle of Kyrgyz has changed with less physical activity and increase in the overall load with fast carbohydrates and saturated fat [3]. Being nomads for

\footnotetext{
*Correspondence: jainagul@mail.ru

'Institute of Molecular Biology and Medicine, 3 Togolok Moldo Street,

720040 Bishkek, Kyrgyzstan

Full list of author information is available at the end of the article
}

centuries with traditional lifestyle and eating habits, Kyrgyz population nowadays experiences the impact of globalized economy and greater role of highly processed foods.

Long-lasting misbalance between calorie intake and energy expenditure will result in the accumulation of visceral adipose tissue, resulting in excess bodyweight and even obesity [4]. Adipose tissue is known to synthesize series of adipocytokines, including leptin, adiponectin, resistin, visfatin, chemerin, vaspin, and apelin which all take part in the carbohydrates and lipids metabolism [5]. Selected adipocytokines synthesized in the adipose tissue may predict quite a range of diseases. Omentin (Intelectin-1: ITLN1, OMIM: 609873) is one of recently discovered secretory proteins of visceral adipose 
tissue with two isoforms identified as omentin-1 and omentin-2 [6]. Omentin may have a serum concentration of 100 to $1 \mu \mathrm{g} / \mathrm{ml}$ [7], dropping to lower levels in patients with obesity, insulin resistance and diabetes type II [7-10]. In these conditions, reduced omentin levels correlate with increased body mass index (BMI), insulin resistance (HOMA-IR), high triglycerides (TG) level and low-density lipoprotein cholesterol [7, 8]. Low blood omentin concentration accompanied reduction in adiponectin and highdensity lipoprotein cholesterol levels $[9,10]$.

Omentin is a 313-amino acid protein with a molecular mass of $38 \mathrm{Kd}$ [11]. The gene to code its amino acid sequence is located in the 1q22-q23 locus of the first chromosome and comprises 8 exons and seven introns [12]. There exists a polymorphic locus in the position 326 of the fourth exon, where adenine is replaced with thymine (326 GAC $\rightarrow$ GTC, rs2274907), which entails the replacement of asparagine with valine in the position 109 of ITLN1 (Val109Asp) [12].

At present, the evidence on the association of ITLN1 gene with obesity is very poor, with only very few studies published [12-14]. To our best knowledge, there are no existing publications on the prevalence of genotypes and alleles of ITLN1 gene Val109Asp polymorphic marker in Kyrgyz population, as well as on its association with abdominal obesity (AO) in Kyrgyz adults, whereas $\mathrm{AO}$ in its turn is closely linked with cardiovascular complications. The aim of this study was to ascertain the risk of AO in Kyrgyz population associated with ITLN1 gene Val109Asp polymorphism.

\section{Methods}

\section{Participants, recruitment and study design}

In this case-control study, we enrolled 297 unrelated subjects with known Kyrgyz ethnic background, of whom 127 subjects were cases, including 46 men and 81 women with the mean age $53.2 \pm 7.1$ years. Subjects were enrolled from the annual screening at a local outpatient facility in Bishkek, where they routinely applied for fitness certificates. Cases had AO, when both body mass index (BMI) exceeded $30 \mathrm{~kg} / \mathrm{m}^{2}$ and waist circumference exceeded $88 \mathrm{~cm}$ in women and $102 \mathrm{~cm}$ in men (FDA criteria, 2005). One hundred and seventy healthy subjects, of whom 61 were men and 109 women with the mean age $52.0 \pm 9.0$ with no known history of AO, cardiovascular diseases and with normal carbohydrate and lipid metabolism were controls.

Both cases and controls in this study were subjected to a uniformed clinical examination, which included anamnesis, anthropometric tests (height, body mass, waist circumference (WC), hip circumference (HC)) with the subsequent calculation of BMI, and blood pressure (BP) measurement (systolic (SBP) and diastolic (DBP). BMI was calculated as height $(\mathrm{m}) /$ body mass $(\mathrm{kg})^{2}$. Obesity was diagnosed with $\mathrm{BMI} \geq 30 \mathrm{~kg} / \mathrm{m}^{2}$. Subjects with $\mathrm{WC}$ $\geq 88 \mathrm{~cm}$ in women and $\geq 102 \mathrm{~cm}$ in men were diagnosed with AO.

We used standard techniques to measure blood sugar, serum total cholesterol (TC), triglycerides (TG), and high-density lipoprotein cholesterol (HDLC) using "Beckman" biochemical analyzer (USA). We used Friedwald formula to calculate low-density lipoprotein cholesterol (LDLC), whereas serum immunoreactive insulin was tested with immunuenzyme analysis in the Hospital Saint-Vincent De Paul's lab (Paris, France). Homeostasis Model Assessment of Insulin Resistance (HOMA-IR) was calculated using the formula: HOMA-IR = serum insulin $(\mu \mathrm{IU} / \mathrm{ml})$ * serum glucose $(\mathrm{mmol} / \mathrm{l}) / 22.5$. We considered IR present when HOMA-IR was equal to or exceeded 2.77 .

\section{DNA extraction and genotyping}

DNA was extracted from peripheral blood white cells via a standard two-stage phenol-chlorophorm method. We then used 5'-GAGCCTTTAGGCCATGTCTCT-3' and 5'-CTCTCСТTCTTCTCCAGCCCAT-3' primers to amplify Val109Asp polymorphic locus of the ITLN1 gene. The ITLN1 gene amplified locus with a length of 471 base pairs (bp) was split into fragments using AccI endonuclease. PCR and restriction data were detected with $3 \%$ agarose gel and then photographed by means of UVP (UK) gel documenting system (Fig. 1).

\section{Statistical analysis}

We used STATISTICA v.7.0. (StatSoft) and GraphPad Prism v 5.0 to run all the statistical tests for this report.

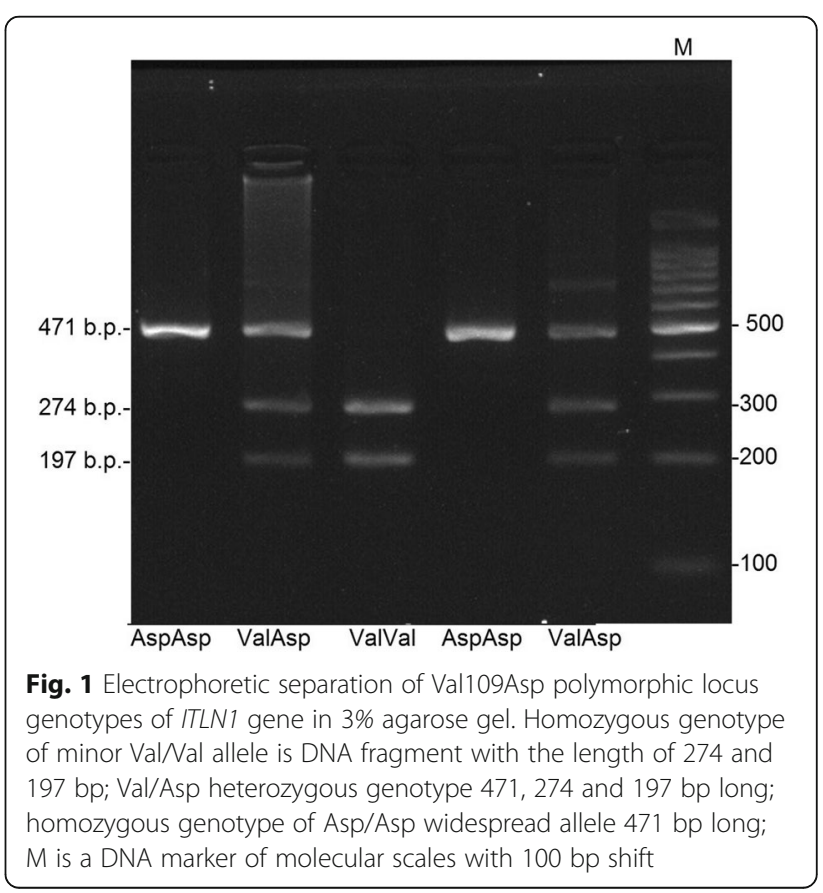


We report quantitative data as mean \pm standard deviation, or as median with the corresponding interquartile range, whereas qualitative data are summarized as absolute number of patients with the corresponding percent of those in the group. In both cases and controls, we tested the frequencies of alleles, allele carriage, as well as genotype frequencies. The deviations of genotype frequencies from Hardy-Weinberg's equilibrium were verified with a Haploview 4.0 free software [http:// www.broad.mit.edu/mpg/haploview]. The frequencies of alleles, allele carriage, as well as genotype frequencies in cases were compared to controls with Fischer exact test in the online version of GraphPad Instat program [http://www.graphpad.com/quickcalcs/index.cfm]. Data are presented as absolute numbers of patients with a given genotype and its corresponding percent in the group. Associations were quantified with the odds ratio (OR) and their corresponding 95\% confidence intervals $(\mathrm{CI})$. The probability of chance lower than $5 \%(p<0.05)$ was considered significant.

\section{Results}

The clinical and biochemical characteristics of patients are shown in Table 1 . There were no statistically significant differences between the groups in terms of sex and age. Patients with AO showed significant lipid and carbohydrate metabolism deviations such as fasting blood glucose, TG and LDLC levels increase, with the corresponding reduction in HDLC. Forty-six (36\%) out of 127 patients with AO had IR, 95 (75\%) had obesity, 69 (54\%) had type 2 diabetes, 69 (54\%) had essential hypertension and 114 (90\%) had metabolic syndrome (MS).

The frequency distribution of Val109Asp polymorphism of ITLN1 gene in controls $\left(\chi^{2}=0.725 ; p=0.394\right)$ and in cases $\left(\chi^{2}=2.768 ; p=0.09\right)$ corresponded to HardyWeinberg's equilibrium. When testing Val109Asp locus of ITLN1 gene in cases in controls, we identified three possible combinations: $\mathrm{Val} / \mathrm{Val}=\mathrm{GTC} / \mathrm{GTC}, \mathrm{Val} / \mathrm{Asp}=$ GAC/GTC and Asp $/$ Asp $=$ GAC/GAC (Table 2). About $50 \%$ of subjects in Kyrgyz population, therefore, carry homozygous genotype of the widespread (major) Asp109Asp allele.

In the univariate comparative analysis, we found statistically significant greater prevalence of homozygous genotype of the less spread (minor) Val109Val allele. The frequency of minor and major alleles in controls was 0.26 and 0.74 , and 0.32 и 0.68 in patients with $\mathrm{AO}\left(\mathrm{x}^{2}=\right.$ $2.54, p=0.11$ ).

\section{Discussion}

This case-control study confirmed the association of Val109Asp polymorphic marker of ITLN1 gene with AO in Kyrgyz population. Whenever homozygous Val109Val

Table 1 Baseline clinical and biochemical data of cases and controls

\begin{tabular}{|c|c|c|c|}
\hline Index & Controls, $n=170$ & Cases, $n=127$ & $p$ \\
\hline Age, years & $52.0 \pm 9.0$ & $53.2 \pm 7.1$ & NS \\
\hline Sex (male), n (\%) & $61(36 \%)$ & $46(36 \%)$ & NS \\
\hline Weight, kg & $64.7 \pm 9.8$ & $83.5 \pm 14.1$ & 0.00001 \\
\hline Essential hypertension, n (\%) & 0 & $69(54.3 \%)$ & - \\
\hline $\mathrm{SBP}, \mathrm{mm} \mathrm{Hg}$ & $122.0 \pm 10.6$ & $148.6 \pm 27.0$ & 0.00001 \\
\hline $\mathrm{DBP}, \mathrm{mm} \mathrm{Hg}$ & $79.3 \pm 9.3$ & $91.7 \pm 14.5$ & 0.00001 \\
\hline Type 2 diabetes, n (\%) & 0 & $69(54 \%)$ & - \\
\hline Blood glucose, $\mathrm{mmol} / \mathrm{l}$ & $5.20[5.01 ; 5.48]$ & $7.33[5.49 ; 8.48]$ & 0.001 \\
\hline MS, n (\%) & 0 & $114(90 \%)$ & - \\
\hline Obesity, n (\%) & 0 & $95(75 \%)$ & - \\
\hline $\mathrm{BMl}, \mathrm{kg} / \mathrm{m}^{2}$ & $24.1 \pm 2.7$ & $31.5 \pm 4.1$ & 0.00001 \\
\hline WC $(\mathrm{cm})$ & $83.2 \pm 8.6$ & $104.1 \pm 9.2$ & 0.00001 \\
\hline $\mathrm{HC}(\mathrm{cm})$ & $95.6 \pm 7.8$ & $109.5 \pm 8.6$ & 0.00001 \\
\hline $\mathrm{TC}, \mathrm{mmol} / \mathrm{l}$ & $5.0 \pm 0.9$ & $5.1 \pm 1.0$ & NS \\
\hline $\mathrm{HDLC}, \mathrm{mmol} / \mathrm{l}$ & $3.2 \pm 0.8$ & $1.0 \pm 0.3$ & 0.00001 \\
\hline LDLC, mmol/l & $1.3 \pm 0.4$ & $3.2 \pm 0.9$ & 0.00001 \\
\hline $\mathrm{TG}, \mathrm{mmol} / \mathrm{l}$ & $1.2 \pm 0.7$ & $2.1 \pm 1.5$ & 0.00001 \\
\hline HOMA-IR & 0 & $46(36 \%)$ & - \\
\hline Insulin, $\mu|U / m|$ & $5.08[3.35 ; 6.65]$ & $12.7[7.52 ; 15.90]$ & 0.001 \\
\hline
\end{tabular}

MS metabolic syndrome, WC waist circumference, $H C$ hip circumference, SBP systolic blood pressure, DBP diastolic blood pressure, $B M I$ body mass index, $T C$ total cholesterol, HDLC high-density lipoprotein cholesterol, $L D L C$ low-density lipoprotein cholesterol, TG triglycerides, NS non-significant, $p$ probability value 
Table 2 The genotype and allele frequencies of Val109Asp polymorphic marker of ITLN1 gene in cases compared to controls

\begin{tabular}{|c|c|c|c|c|}
\hline Genotypes and alleles & Cases, $n=127$ (\%) & Controls, $n=170(\%)$ & $x^{2} ; p$ & OR (95\% Cl) \\
\hline Asp109Asp & $61(48)$ & $90(53)$ & $x^{2}=6.29 ; p=0.043$ & $0.82(0.53-1.30)$ \\
\hline Val109Asp & $51(40)$ & $73(43)$ & & $0.89(0.56-1.42)$ \\
\hline Val109Val & $15(12)$ & $7(4)$ & & $3.12(1.23-7.90)$ \\
\hline Asp & $173(68)$ & $253(74)$ & $x^{2}=2.54 ; p=0.11$ & $0.73(0.51-1.05)$ \\
\hline Val & $81(32)$ & $87(26)$ & & $1.36(0.95-1.95)$ \\
\hline
\end{tabular}

OR odds ratio, $\mathrm{Cl}$ confidence interval; data are presented as absolute number of patients with their percent in the groups, whereas ORs presented with their corresponding $95 \% \mathrm{Cl}$. For ORs, the reference group is a pool of two alternative genotypes

genotype is present, the likelihood of AD increases 3fold $(\mathrm{OR}=3.12$; $95 \%$ CI $1.23-7.90)$. In the given population, significant increase in the frequency of Val109Val genotype of ITLN1 gene in AO patients may be indicative of the association of ITLN1 gene with AO, which requires further investigation.

Statistical power of our case-control study is expected to reach $100 \%$, based on a conventional power calculation for this type of studies. With a number of cases $N=127$, an approximate case/controls ratio 1:1, Z-alpha 1.96 and the OR of the association extracted from the preceding study $(\mathrm{OR}=4.5)$, as well as the percent of exposed controls $10 \%$, the number of patients in our study dramatically exceeds the patients number needed to achieve $80 \%$ power $(N=38)$.

In general, genetic predisposition is a well-studied risk factor for obesity [15], which in turn, especially its abdominal form, is a major risk factor for type 2 diabetes, essential hypertension and MS [1, 16, 17]. At present, adipocytokine family genes attract much attention to study such genetic predisposition to $\mathrm{AO}$ and related conditions, whereas their products, secreted with the visceral adipose tissue and being the link to various metabolic and cellular processes, may directly or indirectly affect carbohydrate and lipid metabolism [6, 15]. ITLN1 gene is one of those recently identified genes, whose product is selectively secreted by the visceral adipose tissue. In 2005, Schaffler et al. [11] studied and published the genome structure, nucleotide sequence, promoter, and exon-intron structure of ITLN1 gene. There were two mononucleotide polymorphisms identified in the fourth exon of ITLN1 gene, including A326T (Val109Asp, rs2274907) and C258T (His86His, rs2274908) [12].

At present, there are only a few studies of the distribution of Val109Asp polymorphism of ITLN1 gene in the European and Asian populations. Thus, minor allele of Val109Asp marker of ITLN1 gene had a 0.18 prevalence in Iranian population [13], 0.22 in Turkish population [14], 0.30 in Czech [18], and 0.31 in subjects with German origin [12]. Our data showed that the prevalence of minor allele in Kyrgyz population does not significantly differ from other populations and equals 0.26 .
Data from this study in comparison with other studies in terms of minor allele frequency (MAF) and the corresponding data are shown in Table 3. When comparing data from other populations, we conclude that, in general, individuals with major allele prevail in total population (72-88\% subjects), whereas $18-31 \%$ carry minor allele.

Available literature data on the association of Val109Asp polymorphic locus of ITLN1 gene with various constituents of MS, including AO, is very scarce. In 2015, a group of authors identified association of Val109Asp locus of ITLN1 gene with daily energy intake in a sample of subjects with Czech origin [18]. In this study, they found a significant difference in genotype distribution when comparing obese and morbidly obese subjects, where AA genotype was significantly less frequent in the morbidly obese cohort and AT genotype, on opposite, was more frequent in the morbidly obese subjects compared to obese group. In another study, those having Val109Val genotype had almost 5-fold increased probability of obesity compared to Asp109Asp carriers $(\mathrm{OR}=4.5 ; 95 \%$ CI 1.3-14.9; $p=0.01)$ [13], whereas minor allele was associated with a 1.5-fold increase in breast cancer risk $(\mathrm{OR}=1.5$; 95\% CI $1-2.20$; $p=0.04)$ [19].

Data on the association of polymorphic variants of Val109Asp ITLN1 gene with the omentin production, functional activity and its blood level are also insufficient. In Czech population, the least omentin blood concentration $(409.7 \pm 169.1 \mu \mathrm{g} / \mathrm{l})$ was detected in subjects with Val109Val genotype, as opposed to its highest concentration of $475.7 \pm 153.7 \mu \mathrm{g} / \mathrm{l}$ in those carrying Asp109Asp variant. Those findings were not, however, significant [18].

Numerous clinical and experimental studies confirmed that omentin was a multifunctional protein, resembling adiponectin in its biological properties, such as vasodilating, anti-inflammatory, immunocompromising and anti-diabetic effects [20, 21]. Blood omentin levels were significantly lessened in patients with obesity, both types of diabetes, endothelial dysfunction and a few cardiovascular diseases [7, 8, 20]. Low blood omentin levels correlate with high body mass index, WC/HC ratio, HOMA-IR, high blood insulin, glucose, 
Table 3 Allele frequency and genotype distribution Val109Asp polymorphic marker of ITLN1 gene in different populations

\begin{tabular}{|c|c|c|c|c|c|c|}
\hline Populations & HWE, $P$ value & Allele & Allele frequency & Genotype & Genotype frequency (\%) & Author(s) \\
\hline \multirow[t]{3}{*}{ Kyrgyz $(n=170)$} & \multirow[t]{3}{*}{$p=0.09$} & Asp & 0.74 & Asp/Asp & $90(53.0)$ & \multirow[t]{3}{*}{ This study } \\
\hline & & \multirow[t]{2}{*}{ Val } & \multirow[t]{2}{*}{0.26} & Val/Asp & $73(43.0)$ & \\
\hline & & & & $\mathrm{Val} / \mathrm{Nal}$ & $7(4.0)$ & \\
\hline \multirow[t]{3}{*}{ Czech $(n=495)$} & \multirow[t]{3}{*}{$p=0.72$} & Asp & 0.70 & Asp/Asp & $240(48.0)$ & \multirow[t]{3}{*}{ Splichal et al., 2015 [18] } \\
\hline & & \multirow[t]{2}{*}{ Val } & \multirow[t]{2}{*}{0.30} & Val/Asp & $207(42.4)$ & \\
\hline & & & & Val/Nal & $48(9.6)$ & \\
\hline \multirow[t]{3}{*}{ Turkey $(n=42)$} & \multirow[t]{3}{*}{$p=0.04$} & Asp & 0.76 & Asp/Asp & $22(52.3)$ & \multirow[t]{3}{*}{ Yaykasli et al., 2013 [22] } \\
\hline & & \multirow[t]{2}{*}{ Val } & \multirow[t]{2}{*}{0.24} & Val/Asp & $20(47.6)$ & \\
\hline & & & & $\mathrm{Val} / \mathrm{Nal}$ & 0 & \\
\hline \multirow[t]{3}{*}{ Turkey $(n=39)$} & \multirow[t]{3}{*}{$p=0.28$} & Asp & 0.88 & Asp/Asp & $25(64.0)$ & \multirow[t]{3}{*}{ Turan, et al., 2013 [14] } \\
\hline & & \multirow[t]{2}{*}{ Val } & \multirow[t]{2}{*}{0.22} & Val/Asp & $11(28.0)$ & \\
\hline & & & & $\mathrm{Val} / \mathrm{Nal}$ & $3(8.0)$ & \\
\hline \multirow[t]{3}{*}{ Germany ( $n=276)$} & \multirow[t]{3}{*}{$p=0.036$} & Asp & 0.72 & Asp/Asp & $138(50.0)$ & \multirow[t]{3}{*}{ Schäffler et al., 2007 [12] } \\
\hline & & \multirow[t]{2}{*}{ Val } & \multirow[t]{2}{*}{0.28} & Val/Asp & $124(44.9)$ & \\
\hline & & & & Val/Nal & $14(5.1)$ & \\
\hline \multirow[t]{3}{*}{$\operatorname{Iran}(n=150)$} & \multirow[t]{3}{*}{$p=0.60$} & Asp & 0.82 & Asp/Asp & $101(67.3)$ & \multirow[t]{3}{*}{ Kohan, 2014 [13] } \\
\hline & & Val & 0.18 & Val/Asp & $43(28.7)$ & \\
\hline & & & & Val/Nal & $6(4.0)$ & \\
\hline
\end{tabular}

HWE Hardy - Weinberg equilibrium

TG and LDLC levels, as well as low adiponectin and HDLC levels $[7,8,10,20]$. These clinical and experimental findings altogether prompt some omentin's contribution to MS and series of cardiovascular conditions associated with that. Given that, low blood omentin level is proposed as a valuable predictor of MS and cardiovascular complications $[5,9,20,21]$.

Despite showing significant associations, reaching high statistical power for such study design and being the first study to verify the magnitude of such association in Kyrgyz population, the limitations of this analysis should also be noted. Thus, we could not support our results with the phenotypic analysis of our population. Because we could not perform serum omentin tests, and adjust them for sex, age and other covariates, our findings have a limited clinical relevance and should be treated appropriate to a specific clinical situation. Besides, AO diagnosis was made without body composition measurements, as they were not available, and we consider this another limitation of our analysis.

We need to state that currently full-genome studies in Kyrgyz Republic are not feasible. Studies on multifactorial diseases in our country are still limited with single nucleotide polymorphism search only. The current study is the first and only to assess Val109Asp polymorphism of ITLN1 gene in the whole Central Asian population, and also one of very few uncovering the association of ITLN1 gene with AO. This study enabled to test the distribution of genotypes and alleles of ITLN1 gene's
Val109Asp polymorphism in Kyrgyz population, as well as to detect significant increase in Val109Val genotype frequency in patients with $\mathrm{AO}$. This may support the hypothesis of the role of ITLN1 in genetic predisposition to AO in the Kyrgyz. Such conclusion clearly needs further confirmation in larger samples and with other genetic markers.

\section{Conclusions}

Significant increase in the frequency of Val109Val genotype of ITLN1 gene in AO patients may be indicative of some potential role of ITLN1 gene in molding genetic predisposition to AO in the Kyrgyz. Identification of candidate genes, which are associated with abdominal obesity in various ethnicities, is relevant for the healthcare. Finding such genotypes and alleles, associated with the disease, will help individualize primary and secondary prevention programs for such patients in order to reduce the risk.

\section{Abbreviations}

AO: Abdominal obesity; BMI: Body mass index; BP: Blood pressure; DBP: Diastolic blood pressure; HC: Hip circumference; ITLN1: Intelectin 1; MS: Metabolic syndrome; PCR: Polymerase chain reaction; SBP: Systolic blood pressure; WC: Waist circumference

\section{Acknowledgements}

We thank all patients for their participation in this study. We would also like to express our gratitude to the National Center of Cardiology and Internal Medicine (Bishkek, Kyrgyz Republic) doctors, Olga Lunegova and Alina Kerimkulova for their help in collecting biosamples and clinical data. 


\section{Funding}

This study was supported by the Ministry of Education and Science of Kyrgyz Republic, State Register \#0005818, dated February 2, 2017.

\section{Availability of data and materials}

The datasets used and/or analysed during the current study available from the corresponding author on reasonable request.

\section{Authors' contributions}

$J$, EM, and AA conceived and designed the experiments. JI and ET carried out the molecular genetic studies, and performed the statistical analysis. J and DV wrote the paper. JI, AA and NA undertook data collection, interpretation of results and edited the manuscript. All authors read and approved the final manuscript.

\section{Ethics approval and consent to participate}

Upon study inception, all subjects were informed about the aim of this project and signed voluntary written consent in either Russian or Kyrgyz. This study protocol fully complied with the ethical standards of the Declaration of Helsinki and was approved by the local IRB of the Scientific Research Institute of Molecular Biology and Medicine in Bishkek (Minutes №\#1, dated January 14, 2016).

\section{Consent for publication}

Not applicable.

\section{Competing interests}

The authors declare that they have no competing interests.

\section{Publisher's Note}

Springer Nature remains neutral with regard to jurisdictional claims in published maps and institutional affiliations.

\section{Author details}

${ }^{1}$ Institute of Molecular Biology and Medicine, 3 Togolok Moldo Street, 720040 Bishkek, Kyrgyzstan. ${ }^{2}$ School of Public Health, al-Farabi Kazakh National University, 71 Al-Farabi avenue, Almaty, Kazakhstan050040. ${ }^{3}$ I.K. Akhunbaev Kyrgyz State Medical Academy, 92 Akhunbaev Street, Bishkek 720020, Kyrgyz Republic

Received: 10 July 2017 Accepted: 19 February 2018

Published online: 27 February 2018

\section{References}

1. World Health Organization. Obesity and overweight. 2013. Ref. source. 2014

2. GHO | By category [Internet]. WHO. [cited 2 May 2017]. Available from: http://apps.who.int/gho/data/view.main.

3. Kyrgyz Livestock Study. Pasture Management and Land Use. | Land Portal [Internet]. [cited 2 May 2017]. Available from: http://landportal.info/library/ resources/kyrgyz-livestock-study-pasture-management-and-land-use.

4. Goettems ML, Schuch HS, Hallal PC, Torriani DD, Demarco FF. Nutritional status and physical activity level as risk factor for traumatic dental injuries occurrence: a systematic review. Dent Traumatol. 2014;30:251-8.

5. Fasshauer M, Blüher M. Adipokines in health and disease. Trends Pharmacol Sci. 2015;36:461-70.

6. Yang R-Z, Lee M-J, Hu H, Pray J, Wu H-B, Hansen BC, et al. Identification of omentin as a novel depot-specific adipokine in human adipose tissue: possible role in modulating insulin action. Am J Physiol Endocrinol Metab. 2006;290:E1253-61.

7. de Souza Batista CM, Yang R-Z, Lee M-J, Glynn NM, Yu D-Z, Pray J, et al. Omentin plasma levels and gene expression are decreased in obesity. Diabetes. 2007:56:1655-61.

8. Tan BK, Adya R, Farhatullah S, Lewandowski KC, O'Hare P, Lehnert H, et al. Omentin-1, a novel adipokine, is decreased in overweight insulin-resistant women with polycystic ovary syndrome. Diabetes. 2008;57:801-8.

9. Auguet T, Quintero Y, Riesco D, Morancho B, Terra X, Crescenti A, et al. New adipokines vaspin and omentin. Circulating levels and gene expression in adipose tissue from morbidly obese women. BMC Med Genet. 2011;12:60.

10. Abd-Elbaky AE, Abo-EIMatty DM, Mesbah NM, Ibrahim SM. Omentin and apelin concentrations in relation to obesity, diabetes mellitus type two, and cardiovascular diseases in Egyptian population. Int J Diabetes Dev Ctries. 2016:36:52-8.
11. Schäffler A, Neumeier $M$, Herfarth $H$, Fürst $A$, Schölmerich J, Büchler C Genomic structure of human omentin, a new adipocytokine expressed in omental adipose tissue. Biochim Biophys Acta. 2005;1732:96-102.

12. Schäffler A, Zeitoun $M$, Wobser $H$, Buechler $C$, Aslanidis $C$, Herfarth $H$. Frequency and significance of the novel single nucleotide missense polymorphism Val109Asp in the human gene encoding omentin in Caucasian patients with type 2 diabetes mellitus or chronic inflammatory bowel diseases. Cardiovasc Diabetol. 2007;6:3.

13. Bahadori M, Kohan $L$, Jafari N. Association of assessment between Val109Asp omentin gene and obesity in Iranian women. Iran J Diabetes Metab. 2015:14:127-32.

14. Turan H, Yaykasli KO, Soguktas H, Yaykasli E, Aliagaoglu C, Erdem T, et al. Omentin serum levels and omentin gene Val109Asp polymorphism in patients with psoriasis. Int J Dermatol. 2014;53:601-5.

15. Nakamura K, Fuster JJ, Walsh K. Adipokines: a link between obesity and cardiovascular disease. J Cardiol. 2014;63:250-9.

16. Schmidt AM. The growing problem of obesity. Arterioscler Thromb Vasc Biol. 2015;35:e19.

17. González N, Moreno-Villegas Z, González-Bris A, Egido J, Lorenzo Ó. Regulation of visceral and epicardial adipose tissue for preventing cardiovascular injuries associated to obesity and diabetes. Cardiovasc Diabetol. 2017:16:44

18. Splichal Z, Bienertova-Vasku J, Novak J, Zlamal F, Tomandl J, Tomandlova M et al. The common polymorphism Val109Asp in the omentin gene is associated with daily energy intake in the central-European population. Nutr Neurosci. 2015;18:41-8.

19. Bahadori M, Kohan L, Farzan M, Aliakbari S, Panah MM. An increased risk of breast cancer associated with Val109Asp polymorphism in omentin gene. Int J Bio Sci. 2014;5:429-34

20. Halabis M, Dziedzic M, Warchulinska J, Kaznowska-Bystryk I, Solski J. Omentin-a new adipokine with many roles to play. Curr Issues Pharm Med Sci. 2015;28:176-80.

21. Zhou J-Y, Chan L, Zhou S-W. Omentin: linking metabolic syndrome and cardiovascular disease. Curr Vasc Pharmacol. 2014;12:136-43.

22. Yaykasli KO, Yaykasli $\mathrm{E}$, Ataoglu S, Ozsahin M, Memisogullari R, Celebi $\mathrm{E}$, et a. The frequency of omentin Val109Asp polymorphism and the serum level of omentin in patients with rheumatoid arthritis. Acta Medica Mediterr. 2013; 29:521-6.

\section{Submit your next manuscript to BioMed Central and we will help you at every step:}

- We accept pre-submission inquiries

- Our selector tool helps you to find the most relevant journal

- We provide round the clock customer support

- Convenient online submission

- Thorough peer review

- Inclusion in PubMed and all major indexing services

- Maximum visibility for your research

Submit your manuscript at www.biomedcentral.com/submit

Biomed Central 